\title{
外来種ココポーマアカフジツボの国内分布
}

\author{
山口寿之

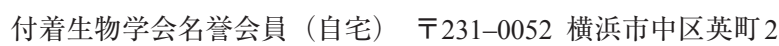

\section{Geographic distribution on the Introduced barnacle Megabalanus coccopoma (Darwin 1854) in Japan}

\author{
Toshiyuki Yamaguchi \\ Honorary Member of the Sessile Organisms Society of Japan, (Home address), 2 Hanabusa-cho, Naka-ku, Yokohama 231-0052, Japan \\ *Corresponding author: Toshiyuki YamaguchiＥ-mail: tyamaguc@msi.biglobe.ne.jp
}

(Received September 10, 2014; Accepted October 10, 2014; Published Online December 25, 2014)

\begin{abstract}
The Titan Acorn barnacle Megabalanus coccopoma was described by Darwin (1854) from the Pacific coast of Panama. Since then, barnacle has became well-known as the introduced barnacle along the Atlantic coasts of Brazil, the USA, and Europe. As was reported in 2009, M. coccopoma was first detected in Japan on September 22, 2007, at the Port of Mizushima in Okayama Prefecture on the hull of an iron-ore carrier that had mainly being cruising between Japan and Australia, then also from the some points of Japanese coast and in various eastern Australian ports (Yamaguchi et al., 2009). In this paper, the current geographic distribution of M. coccopoma in Japan is reported. Also re-examination of my older collections has resulted in a few earlier confirmed records of this barnacles in Japan, in 1978 on oil tanker in the Port of Chiba and in 1981 and 1982 on fishing-net buoys in the Cape Muroto.
\end{abstract}

Keywords: Introduced barnacle, Megabalanus coccopoma (Darwin 1854), Present geographic distribution in Japan

\section{緒言}

ココポーマアカフジッボ Megabalanus coccopomaは、 Darwin（1854）によりパナマ太平洋岸から記載された。 その後、ブラジル、米合衆国、欧州の大西洋岸で外来 種として良く知られるようになった。日本では2007年 9月 22 日に岡山水島港で主に日本-オーストラリア間の 鉄鉱石運搬船の船底から採集され、その後いくつかの日 本の沿岸で、そしてオーストラリア東岸で採集された (Yamaguchi et al. 2009)。本報告は本種の日本国内での分 布の現状と過去に採集され同定されずにいた歴史的コレ クションの調査結果をまとめたものである。

\section{材料と方法}

本種は主に船底などへの付着が知られるので、北海道 から鹿児島・種子島までの地域 (合計 302 地点) で、ドッ ク入りした船舶、航路標識の灯浮標、定置網・ブイなど の漁具を対象として港湾・漁港の他に、岩礁域への付着 調査を行った（Table 1, Fig. 1)。

同定は、Yamaguchi et al. (2009) や山口ほか (2011) が 記述した形態的特徴の記述に基いた。

\section{結果}

Table 1は、はじめの3 地点（赤文字で記載）を除き、 観察地点、観察日、付着基板の種類、採集者（観察者）、 緯度、経度、共存フジッボ類を、北から南に順に配列し
たものである。

ココポーマアカフジッボが確認できなった地点は、 Table 1では塗りつぶしの無い白色で、Fig. 1 では白色の シンボルで示した。ココポーマアカフジツボが確認でき た地点は Table 1ではピンク色または黄緑色に塗りつぶ し、Fig. 1ではピンク色のシンボル (灯浮標など)、淡青 色のシンボル (岩礁) で示した。

堀越・岡本（2007）は、東京湾に設置された灯浮標に 付着したフジッボ類の調査を行った。灯浮標は長期にわ たって定点に設置され、2から 3 年間隔でメンテナンス 作業のために陸揚げ・交換されるので、移入種や付着生 物の動態の監視のためには有効なツールと言える。灯浮 標を利用した堀越・岡本 (2007) の手法は先駆的な研究 と言って良い。ただ当時はココポーマアカフジツボが日 本に移入したことが確認されていなかったので、堀越・ 岡本（2007）はココポーマアカフジッボを全てアカフジ ツボと間違って同定することになった。それらの標本類 は再鑑定され、多くのアカフジツボがココポーマアカフ ジッボと同定された（山口ほか, 2010）。

Table 1の黄緑色の地点の標本は、堀越・岡本 (2007) で東京湾の灯浮標の調査を行った際に採集された資料を 含め、その後海上保安庁の許可のもとに採集された航路 標識 (灯浮標、第二管区・東北、第三管区・関東、第五 管区・近畿-瀬戸内、第六管区 - 五島列島-北九州-関門) から採集された標本類と共に、大阪市立自然史博物館に 
Table 1. List of localities surveyed for Megabalanus coccopoma (Darwin 1854) in Japan. Red type (top three lines) shows data based on my older collections from the hull of the oil tanker "Tokuyama-maru" on August 11, 1978 at the Port of Chiba, and from fishing-net buoys at Cape Muroto, Shikoku at July 27, 1981 and January 22, 1982. Blue font (line 4) shows the first discovery of M. coccopoma at the Port of Mizushima in Okayama. Black font (rest of table) indicates data based on surveys conducted thereafter. Except for the top four lines, locality data were listed from north to south. A light green or pink background indicates sites where M. coccopoma was present; at all other sites, this species was absent. In particular, light green indicates barnacle samples collected from light buoys and preserved in the Osaka Museum of Natural History. Generic abbreviations: A., Amphibalanus; B., Balanus s.s.; Chi., Chirona; Cht., Chthamalus; F., Fistrobalanus; L., Lepas; M., Megabalanus: S., Semibalanus; T., Tetraclita.

\begin{tabular}{|c|c|c|c|c|c|c|}
\hline 日付 & $\begin{array}{c}\text { 産地 } \\
\end{array}$ & 付着物 & 採集者 & $\begin{array}{l}\text { 緯度 } \\
\end{array}$ & 経度 & 共存 \\
\hline 1978.08 .11 & 出光タンカー徳山丸@千葉港 & 船底 & 出光石油 & 不明 & 不明 & M.coccopoma \\
\hline 1981.07.27 & 室戸岬大式網 ～～～～～～ & ブイ & 浦吉德 & $33-16-00 \mathrm{~N}$ & $134-09-00 \mathrm{E}$ & M.coccopoma, M.rosa, B.trigonus \\
\hline 1982.01.22 & 室戸胛大式網 & ブイ & 浦吉徳 & $33-16-00 \mathrm{~N}$ & 134-09-00 E & M.coccopoma, M.rosa, B.trigonus \\
\hline 2007.09 .22 & 新日鵬@岡山県水島港 & 船底 & 山口 & $34-29-23 \mathrm{~N}$ & $133-44-07 \mathrm{E}$ & M.coccopoma, M.rosa, M.volcano \\
\hline 2009.09 .03 & 北海道電力苫東火力発電所 & 取水口 & & $42-36-16.37 \mathrm{~N}$ & $141-48-11.76 \mathrm{E}$ & S.cariosus, B.rostratus, M. rosa \\
\hline 2009.10 .07 & 越喜来 & 漁具 & $\begin{array}{l}\text { 加戸隆介・山 } \\
\text { 口 }\end{array}$ & $39-4-49 \mathrm{~N}$ & $141-52-20 \mathrm{E}$ & M.coccopoma \\
\hline 2009.09 .14 & 気仙沼 & 灯浮標 & 山口 & $38-50-22.5 \mathrm{~N}$ & $141-36-35.2 \mathrm{E}$ & M.rosa, S.cariosus, B.trigonus, A.eburneus \\
\hline 2009.10 .05 & 志津川 & 灯浮標 & 山口 & $38-39-13 \mathrm{~N}$ & $141-32-52 \mathrm{E}$ & M.coccopoma \\
\hline 2005.05 .11 & 宮城県三陸町志津川 & ブイ & 野方靖行 & $38-38-56 \mathrm{~N}$ & $141-31-25 \mathrm{E}$ & M.coccopoma \\
\hline 2009.09 .11 & 石巻4 & 灯浮標 & 山口 & $38-24-28.6 \mathrm{~N}$ & $141-16-20.8 \mathrm{E}$ & A.amphitrite, S.cariosus, B.crenatus \\
\hline 2009.09 .11 & 石巻 1 & 灯浮標 & 山口 & $38-23-49.8 \mathrm{~N}$ & $141-15-34.6 \mathrm{E}$ & M.coccopoma, M.rosa, F.albicostatus, B.rostratus \\
\hline 2009.09 .11 & 石巻3 & 灯浮標 & 山口 & $38-23-31.7 \mathrm{~N}$ & 141-16-11.1 E & A.amphitrite, B.crenatus \\
\hline 2012.09.25-9 & 新潟県佐渡市 高千漁港 & 漁具 & 山口 & $38-11-54.65 \mathrm{~N}$ & $138-20-11.61 \mathrm{E}$ & M.rosa, M.volcano, B.trigonus \\
\hline 2012.09.25-8 & 新潟県佐渡市 高千漁港 & 漁具 & 山口 & $38-10-39.54 \mathrm{~N}$ & $138-18-54.20 \mathrm{E}$ & \\
\hline 2012.09.25-7 & 新潟県佐渡市 平根崎漁港 & 漁具 & 山口 & $38-7-12.64 \mathrm{~N}$ & $138-16-20.51 \mathrm{E}$ & \\
\hline 2012.09.25-10 & 新潟県佐渡市 両津漁港 & 漁具 & 山口 & $38-5-32.81 \mathrm{~N}$ & $138-26-8.22 \mathrm{E}$ & B.trigonus, M.rosa \\
\hline 2012.09.24-3 & 新潟県佐渡市 両津大川 & 漁具 & 山口 & $38-4-51.61 \mathrm{~N}$ & $138-32-44.33 \mathrm{E}$ & M.rosa, B.trigonus \\
\hline 2012.09.24-2 & 新潟県佐渡市 入桑漁港 & 漁具 & 山口 & $38-4-39.73 \mathrm{~N}$ & $138-32-6.53 \mathrm{E}$ & M.rosa \\
\hline $2012.09 .25-6$ & 新潟県佐渡市 姫津漁港(達者地区) & 漁具 & 山口 & $38-4-27.29 \mathrm{~N}$ & $138-14-43.50 \mathrm{E}$ & B.trigonus, M.rosa, L. sp \\
\hline $2012.09 .23-1$ & 新潟県佐渡市 両尾漁港 & 漁具 & 山口 & $38-4-22.43 \mathrm{~N}$ & $138-31-32 \mathrm{E}$ & \\
\hline 2012.09.24-5 & 新潟県佐渡市 水津 (片野尾) 漁港 & 漁具 & 山口 & $38-2-58.92 \mathrm{~N}$ & $138-33-54.80 \mathrm{E}$ & M.rosa, B.trigonus \\
\hline $2012.09 .25-5$ & 新潟県佐渡市 相川漁港 & 漁具 & 山口 & $38-1-21.34 \mathrm{~N}$ & $138-13-27.96 \mathrm{E}$ & \\
\hline $2012.09 .25-2$ & 新潟県佐渡市 沢根漁港 & 漁具 & 山口 & $38-0-21.43 \mathrm{~N}$ & $138-16-56.43 \mathrm{E}$ & B.trigonus, M.rosa \\
\hline $2012.09 .25-3$ & 新潟県佐渡市 二見漁港 & 漁具 & 山口 & $37-58-36.55 \mathrm{~N}$ & $138-15-31.30 \mathrm{E}$ & B.trigonus, M.rosa \\
\hline 2012.09.24-6 & 新潟県佐渡市 豊岡漁港 & 漁具 & 山口 & $37-58-35.47 \mathrm{~N}$ & $138-31-15.87 \mathrm{E}$ & B.trigonus \\
\hline $2012.09 .25-4$ & 新潟県佐渡市 稲鯨漁港 & 漁具 & 山口 & $37-58-21.11 \mathrm{~N}$ & $138-14-15.55 \mathrm{E}$ & B.trigonus, M.rosa, B.rostratus \\
\hline $2012.09 .25-1$ & 新潟県佐渡市 豊田漁港 & 漁具 & 山口 & $37-57-29.64 \mathrm{~N}$ & $138-20-10.04 \mathrm{E}$ & B.trigonus, M.rosa \\
\hline 2012.09.24-7 & 新潟県佐渡市 岩首漁港 & 漁具 & 山口 & $37-56-40.18 \mathrm{~N}$ & $138-30-12.09 \mathrm{E}$ & \\
\hline 2012.09.24-8 & 新潟県佐渡市 多田漁港 & 漁具 & 山口 & $37-54-44.59 \mathrm{~N}$ & $138-28-58.36 \mathrm{E}$ & B.trigonus, M.rosa, A.amphitrite \\
\hline 2012.09.24-9 & 新潟県佐渡市 赤泊漁港 & 漁具 & 山口 & $37-52-6.27 \mathrm{~N}$ & $138-24-41.74 \mathrm{E}$ & B.trigonu, M.rosa, B.rostratus \\
\hline 2012.09.24-11 & | 新潟県佐渡市 西三川漁港 & 漁具 & 山口 & $37-52-23.48 \mathrm{~N}$ & $138-17-10.87 \mathrm{E}$ & B.trigonus, M.rosa \\
\hline 2012.09.24-10 & 新潟県佐渡市 小木漁港 & 漁具 & 山口 & $37-48-46.79 \mathrm{~N}$ & $138-16-33.32 \mathrm{E}$ & \\
\hline 2013.05.18-2 & 島根県隠岐郡隠岐の島町中村漁港 & 漁具 & 山口 & $36-19-20.58 \mathrm{~N}$ & $133-18-20.08 \mathrm{E}$ & B.trigonus, A.ebruneus, F.albicostatus \\
\hline 2013.05.19-1 & 島根県隠岐郡隠岐の島町重栖漁港 & 漁具 & 山口 & $36-17-18.54 \mathrm{~N}$ & $133-12-47.39 \mathrm{E}$ & $\begin{array}{l}\text { M.rosa, M.volcano, A.ebruneus, A.amphitrite, } \\
\text { F.albicostatus }\end{array}$ \\
\hline 2013.05.19-2 & 島根県隠岐郡隠岐の島町油井漁港 & 漁具 & 山口 & $36-14-30.96 \mathrm{~N}$ & $133-11-29.53 \mathrm{E}$ & M.rosa, M.volcano, B.trigonus \\
\hline $2013.05 .18-3$ & 島根県隠岐郡隠岐の島町飯田港 & 漁具 & 山口 & $36-13-2.48 \mathrm{~N}$ & $133-20-56.59 \mathrm{E}$ & B.trigonus \\
\hline 2013.05.17-1 & 島根県隱岐郡沖の島町西郷 西郷港東 & 漁具 & 山口 & $36-12-33.60 \mathrm{~N}$ & $133-20-14.75 \mathrm{E}$ & M.rosa, B.trigonus, A.ebruneus \\
\hline 2013.05.19-3 & 島根県隠岐郡隠岐の島町都万漁港 & 漁具 & 山口 & $36-11-19.18 \mathrm{~N}$ & $133-14-7.75 \mathrm{E}$ & M.rosa, B.trigonus \\
\hline 2013.05.18-1 & $\begin{array}{l}\text { 島根県隠岐郡隠岐の島町津戸 隠岐の } \\
\text { 島ダイビングショップ彩 前 }\end{array}$ & 漁具 & 山口 & $36-10-28.98 \mathrm{~N}$ & $133-14-59.13 \mathrm{E}$ & B.trigonus, F.albicostatus \\
\hline 2009.12 .14 & 三浦市南下浦町金田金田漁協 & 漁網 & 山口 & $35-9-32 \mathrm{~N}$ & $139-40-01 \mathrm{E}$ & M.coccopoma, M.rosa, B.trigonus, A. amphitrite \\
\hline 2009.05 .12 & 鹿島2 & 灯浮標 & $\begin{array}{l}\text { 山田和洋·木 } \\
\text { 内将史 }\end{array}$ & $35-58-24 \mathrm{~N}$ & $140-42-23 \mathrm{E}$ & M.coccopoma, M.rosa \\
\hline 2009.05.11 & 鹿島6 & 灯浮標 & 山田・木内 & $35-56-15 \mathrm{~N}$ & $140-42-15 \mathrm{E}$ & M.coccopoma, M.rosa \\
\hline 2012.06.15-2 & 千葉県外川漁港浮きいけすのフロート & 漁具 & 山口 & $35-41-51.74 \mathrm{~N}$ & $140-51-5.17 \mathrm{E}$ & M.coccopoma \\
\hline 2008.05.07 & 千葉 銚子外川 & 岩礁 & 山口 & $35-41-38 \mathrm{~N}$ & $140-51-26 \mathrm{E}$ & M.coccopoma \\
\hline 2009.11.06 & 千葉港市川7 & 灯浮標 & 木内·藤本顕 & $35-39-57 \mathrm{~N}$ & $139-57-13 \mathrm{E}$ & \\
\hline 2009.11.06 & 千葉港市川6 & 灯浮標 & 木内·藤本 & $35-39-26 \mathrm{~N}$ & $139-57-46 \mathrm{E}$ & \\
\hline 2009.11.06 & 千葉港市川5 & 灯浮標 & 木内·藤本 & $35-39-22 \mathrm{~N}$ & $139-57-37 \mathrm{E}$ & \\
\hline 2009.11.06 & 千枼港市川3 & 灯浮標 & 木内·藤本 & $35-38-46 \mathrm{~N}$ & $139-58-3 \mathrm{E}$ & \\
\hline 2009.11.04 & 船橋8 & 灯浮標 & 山口 & $35-38-43 \mathrm{~N}$ & $139-59-16 \mathrm{E}$ & $\begin{array}{l}\text { A.amphitrite, A.ebruneus, A.improvisus, M.rosa, } \\
\text { B.zhujiangensis ?, Cht.challengeri }\end{array}$ \\
\hline 2004.09 .27 & 市川2 & 灯浮標 & $\begin{array}{l}\text { 堀越彩香·岡 } \\
\text { 本研 }\end{array}$ & $35-38-15 \mathrm{~N}$ & $139-58-36 \mathrm{E}$ & M.coccopoma \\
\hline 2009.08 .24 & 東京第六台場西 & 灯浮標 & 山口 & $35-37-58 \mathrm{~N}$ & $139-45-58 \mathrm{E}$ & A.ebrneus, A.amphitrite \\
\hline 2009.09 .01 & 船橋5 & 灯浮標 & 山口 & $35-37-30 \mathrm{~N}$ & 139-59-01 E & $\begin{array}{l}\text { M.coccopoma, A.amphitrite, A.ebruneus, B.trigonus, } \\
\text { A.reticulatus, Cht.challengeri }\end{array}$ \\
\hline 2009.09 .01 & 船橋6 & 灯浮標 & 山口 & $35-37-30 \mathrm{~N}$ & $139-59-12 \mathrm{E}$ & $\begin{array}{l}\text { M.coccopoma, A.amphitrite, A.ebruneus, B.trigonus, } \\
\text { A.reticulatus, Cht.challengeri }\end{array}$ \\
\hline 2009.08 .28 & 東京青梅4 & 灯浮標 & 木内 & $35-37-24 \mathrm{~N}$ & $139-45-55 \mathrm{E}$ & A.eburneus \\
\hline 2009.08.28 & 東京青梅1 & 灯浮標 & 木内 & $35-36-54 \mathrm{~N}$ & $139-45-52 \mathrm{E}$ & A.eburneus \\
\hline 2009.08 .24 & 東京分岐水路 1 & 灯浮標 & 山口 & $35-36-3 \mathrm{~N}$ & $139-47-17 \mathrm{E}$ & A.eburneus, A.amphitrite \\
\hline 2009.11 .04 & 船橋4 & 灯浮標 & 山口 & $35-36-21 \mathrm{~N}$ & $139-59-10 \mathrm{E}$ & $\begin{array}{l}\text { M.coccopoma, A.amphitrite, A.ebruneus, A.improvisus, } \\
\text { B.trigonus, }\end{array}$ \\
\hline
\end{tabular}


Table 1. Continued.

\begin{tabular}{|c|c|c|c|c|c|c|}
\hline 日付 & 産地 & 付着物 & 採集者 & 緯度 & 経度 & 共存 \\
\hline 2010.0107 & 千葉港11 & 灯浮標 & 山口 & $35-35-36 \mathrm{~N}$ & $140-5-12 \mathrm{E}$ & B.eburneus, A.amphitrite \\
\hline 2010.0107 & 千葉港14 & 灯浮標 & 山口 & $35-35-22 \mathrm{~N}$ & $140-5-57 \mathrm{E}$ & B.eburneus, A.amphitrite \\
\hline 2004.09 .27 & 船橋2 & 灯浮標 & 堀越·岡本 & $35-35-09 \mathrm{~N}$ & $139-59-08 \mathrm{E}$ & M.соссорота \\
\hline 2009.12 .24 & 船橋1 & 灯浮標 & 山口 & $35-35-09 \mathrm{~N}$ & $139-58-56 \mathrm{E}$ & $\begin{array}{l}\text { M.coccopoma, A.improvisus, M.rosa, B.trigonus, } \\
\text { A.ebruneus, A.amphitrite }\end{array}$ \\
\hline 2010.02 .15 & 東京西4 & 灯浮標 & 山口 & $35-34-57 \mathrm{~N}$ & $139-48-05 \mathrm{E}$ & B.trigonus, A.ebruneus, A.amphitrite, M.rosa \\
\hline 2009.01.06 & 新日鵬@JFE千葉 & 船底 & 山口ほか & $35-34-54 \mathrm{~N}$ & $140-6-17 \mathrm{E}$ & M.coccopoma, M.rosa \\
\hline $2013.05 .16-3$ & 島根県八束郡美保関町七類漁港 & 漁具 & 山口 & $35-34-15.60 \mathrm{~N}$ & $133-13-27.35 \mathrm{E}$ & M.rosa, B.trigonus \\
\hline 2010.02 .15 & 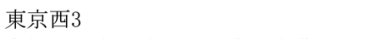 & 灯浮標 & 山口 & $35-34-13 \mathrm{~N}$ & $139-48-18 \mathrm{E}$ & \\
\hline 2013.05.16-4 & 島根県八束郡美保関町片江漁港 & 漁具 & 山口 & $35-33-37.49 \mathrm{~N}$ & $133-11-24.36 \mathrm{E}$ & M.rosa, B.trigonus \\
\hline 2016.05.16-2 & 島根県八束郡美保関町美保関漁港 & 漁具 & 山口 & $35-33-28.93 \mathrm{~N}$ & $133-18-27.75 \mathrm{E}$ & M.rosa, B.trigonus \\
\hline 2010.02.17 & 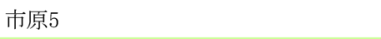 & 灯浮標 & 山口 & $35-33-17 \mathrm{~N}$ & $140-4-18 \mathrm{E}$ & B.trigonus, A.ebruneus, A.amphitrite, A.improvisus \\
\hline 2010.02 .15 & 東京西2 & 灯浮標 & 山口 & $35-33-15 \mathrm{~N}$ & $139-50-33 \mathrm{E}$ & M.coccopoma, A.amphitrite \\
\hline 2010.02 .17 & 市原6 & 灯浮標 & 山口 & $35-33-09 \mathrm{~N}$ & $140-04-13 \mathrm{E}$ & M.coccopoma, B.trigonus, A.ebruneus, A.amphitrite \\
\hline 2013.05.16-01 & 鳥取県境港市境港 & 漁具 & 山口 & $35-31-45.84 \mathrm{~N}$ & $133-14-44.65 \mathrm{E}$ & M.rosa, B.trigonus, A.ebruneus \\
\hline 2009.05 .25 & 東京湾浮標 多摩川 & 灯浮標 & 山口・木内 & $35-31-25 \mathrm{~N}$ & $139-47-39 \mathrm{E}$ & M.coccopoma (dead) \\
\hline 2010.02 .16 & 千葉港千種3 & 灯浮標 & 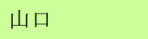 & $35-31-13 \mathrm{~N}$ & $140-01-42 \mathrm{E}$ & M.coccopoma, B.trigonus, A.ebruneus \\
\hline 2009.05 .26 & 東京湾浮標 川崎3 & 灯浮標 & $\begin{array}{l}\text { 山田·木内·山 } \\
\text { 口 }\end{array}$ & $35-30-20 \mathrm{~N}$ & $139-46-38 \mathrm{E}$ & M.coccopoma (dead) \\
\hline 2000.04 .17 & 神奈川 川崎 東扇島火力発電所 & プラント & 野方 & $35-29-51 \mathrm{~N}$ & $139-44-38 \mathrm{E}$ & М.соссорота \\
\hline 2009.11 .02 & $\begin{array}{l}\text { Jamstecなつしま@鶴見ユニバーサル造 } \\
\text { 船 }\end{array}$ & 船底 & 山口 & $35-29-34 \mathrm{~N}$ & $139-41-33 \mathrm{E}$ & $\begin{array}{l}\text { バウスラスター: M.coccopoma, Conchoderma auritum, } \\
\text { M.rosa, A.amphitrite, B.zhujiangensis ?, シーチェスト: } \\
\text { M.coccopoma, A.amphitrite, B.trigonus, 方向蛇: } \\
\text { M.coccopoma, A.amphitrite, L.anatifera }\end{array}$ \\
\hline 2004.08 .30 & 北袖1 & 灯浮標 & 堀越·岡本 & $35-29-03 \mathrm{~N}$ & $139-58-58 \mathrm{E}$ & M.coccopoma \\
\hline 2008.07 .25 & 東京湾浮標 千葉港北袖ヶ浦1 & 灯浮標 & 山口ほか & $35-29-03 \mathrm{~N}$ & $139-58-58 \mathrm{E}$ & M.соссорота \\
\hline 2010.02 .16 & 千葉港北袖2 & 灯浮標 & 山口 & $35-28-55 \mathrm{~N}$ & $139-58-53 \mathrm{E}$ & M.coccopoma, B.trigonus, A.ebruneus, M.rosa \\
\hline 2008.09 .04 & 東京湾浮標 千葉港北袖ヶ浦3 & 灯浮標 & 山口ほか & $35-28-46 \mathrm{~N}$ & $139-59-34 \mathrm{E}$ & M.coccopoma, M.rosa \\
\hline 2008.09 .03 & 東京湾浮標 千葉港中袖地先 & 灯浮標 & 山口ほか & $35-28-41 \mathrm{~N}$ & $139-58-51 \mathrm{E}$ & M.coccopoma \\
\hline 2008.09 .04 & 東京湾浮標 千葉港北袖ヶ浦 4 & 灯浮標 & 山口ほか & $35-28-41 \mathrm{~N}$ & $139-59-22 \mathrm{E}$ & M.coccopoma \\
\hline 2008.07.25 & 東京湾浮標 播洲沖C & 灯浮標 & 山口ほか & $35-28-11 \mathrm{~N}$ & $139-57-02 \mathrm{E}$ & M.соссорота \\
\hline 2009.05 .26 & 東京湾浮標 神奈川5 & 灯浮標 & $\begin{array}{l}\text { 山田・木内・山 } \\
\text { 口 }\end{array}$ & $35-28-09 \mathrm{~N}$ & $139-39-32 \mathrm{E}$ & M.coccopoma (dead) \\
\hline 2004.09 .16 & 播州沖B & 灯浮標 & 堀越·岡本 & $35-27-24 \mathrm{~N}$ & $139-53-42 \mathrm{E}$ & M.coccopoma \\
\hline 2004.09 .16 & 播州沖A & 灯浮標 & 堀越·岡本 & $35-25-39 \mathrm{~N}$ & $139-52-00 \mathrm{E}$ & M.coccopoma \\
\hline 2009.08 .25 & 本牧沖 & 灯浮標 & 山口 & $35-25-09 \mathrm{~N}$ & $139-41-37 \mathrm{E}$ & $\begin{array}{l}\text { M.coccopoma, M.rosa, A.amphitrite, A.ebruneus, } \\
\text { B.trigonus }\end{array}$ \\
\hline 2009.11 .22 & 中/瀬D & 灯浮標 & 山口 & $35-24-53 \mathrm{~N}$ & $139-45-19 \mathrm{E}$ & $\begin{array}{l}\text { M.coccopoma, M.rosa, A.amphitrite, A.improvisus, } \\
\text { A.ebruneus, B.trigonus }\end{array}$ \\
\hline 2009.08 .25 & 横浜根岸7 & 灯浮標 & 山口 & $35-24-14 \mathrm{~N}$ & 139-39-08 E & $\begin{array}{l}\text { M.coccopoma, M.rosa, A.amphitrite, A.ebruneus, } \\
\text { B.trigonus }\end{array}$ \\
\hline 2010.01 .21 & 横浜根岸5 & 灯浮標 & 山口 & $35-23-51 \mathrm{~N}$ & $139-39-46 \mathrm{E}$ & M.coccopoma, M.rosa, B.trigonus, A.ebruneus \\
\hline 2009.02 .25 & 東京湾浮標 木更津港5 & 灯浮標 & 山口ほか & $35-23-21 \mathrm{~N}$ & $139-49-51 \mathrm{E}$ & M.coccopoma, M.rosa \\
\hline 2010.01 .21 & 横浜根岸3 & 灯浮標 & 山口 & $35-23-11 \mathrm{~N}$ & $139-40-30 \mathrm{E}$ & $\begin{array}{l}\text { M.coccopoma, M.rosa, B.trigonus, A.ebruneus, } \\
\text { B.zhujiangensis ?, Cht.challengeri }\end{array}$ \\
\hline 2004.11 .26 & 中ノ瀬航路6 & 灯浮標 & 堀越·岡本 & $35-23-10 \mathrm{~N}$ & $139-46-03 \mathrm{E}$ & M.coccopoma \\
\hline 2009.02 .25 & 東京湾浮標 木更津港6 & 灯浮標 & 山口ほか & $35-23-08 \mathrm{~N}$ & $139-49-42 \mathrm{E}$ & M.coccopoma, M.rosa \\
\hline 2004.09 .28 & 中/瀬西方1 & 灯浮標 & 堀越·岡本 & $35-22-55 \mathrm{~N}$ & $139-42-30 \mathrm{E}$ & M.coccopoma \\
\hline 2010.01 .21 & 横浜根岸1 & 灯浮標 & 山口 & $35-22-52 \mathrm{~N}$ & $139-41-57 \mathrm{E}$ & $\begin{array}{l}\text { M.coccopoma, M.rosa, B.trigonus, A.amphitrite, } \\
\text { A.ebruneus, B.zhujiangensis? }\end{array}$ \\
\hline 2008.10 .03 & 東京湾浮標 木更津富津3 & 灯浮標 & 山口ほか & $35-22-21 \mathrm{~N}$ & $139-48-34 \mathrm{E}$ & M.coccopoma \\
\hline 2004.09 .29 & 木更津富津4 ～～～～～～～～～～～ & 灯浮標 & 堀越·岡本 & $35-22-16 \mathrm{~N}$ & $139-48-17 \mathrm{E}$ & M.coccopoma \\
\hline 2008.10 .03 & 東京湾浮標 木更津港富津4 & 灯浮標 & 山口ほか & $35-22-16 \mathrm{~N}$ & $139-48-17 \mathrm{E}$ & M.coccopoma, M.rosa \\
\hline 2004.09 .21 & 中/瀬航路4 & 灯浮標 & 堀越·岡本 & $35-22-05 \mathrm{~N}$ & $139-45-33 \mathrm{E}$ & M.coccopoma \\
\hline 2009.08 .20 & 木更津港富津7 & 灯浮標 & 山口 & $35-21-23 \mathrm{~N}$ & $139-48-56 \mathrm{E}$ & M.coccopoma, M.rosa \\
\hline 2009.08 .20 & 木更津港富津9 & 灯浮標 & 山口 & $35-20-53 \mathrm{~N}$ & $139-49-10 \mathrm{E}$ & M.coccopoma, M.rosa \\
\hline 2009.09 .05 & 横須賀港沖の根 & 灯浮標 & 山田 & $35-20-11 \mathrm{~N}$ & $139-40-54 \mathrm{E}$ & M.coccopoma, M.rosa, B.trigonus, A.amphitrite \\
\hline 2004.12.01 & 浦賀水道航路6 & 灯浮標 & 堀越·岡本 & $35-19-47 \mathrm{~N}$ & $139-43-23 \mathrm{E}$ & M.coccopoma \\
\hline 2009.01 .08 & 東京湾浮標＼cjkstart浦賀水道航路8 & 灯浮標 & 山口ほか & $35-19-47 \mathrm{~N}$ & $139-43-23 \mathrm{E}$ & M.coccopoma, M.rosa \\
\hline 2008.11 .09 & 東京湾浮標 浦賀水道航路中央6 & 灯浮標 & 山口ほか & $35-19-46 \mathrm{~N}$ & $139-42-49 \mathrm{E}$ & M.coccopoma, M.rosa \\
\hline 2009.05 .27 & 東京湾浮標 浦賀7 & 灯浮標 & 山田 & $35-19-46 \mathrm{~N}$ & $139-42-15 \mathrm{E}$ & M.coccopoma \\
\hline 2005.01 .27 & 神奈川 茅ヶ崎 & 岩礁 & 大谷 & $35-19-02 \mathrm{~N}$ & 139-24-04 E & M.coccopoma \\
\hline 2009.12 .28 & 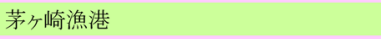 & 灯浮標 & 山口 & $35-18-58 \mathrm{~N}$ & $139-23-51 \mathrm{E}$ & M.coccopoma, L. sp., A.amphitrite \\
\hline 2011.02 .17 & 平塚市千石河岸 新港 定置網 & 漁具 & 山口 & $35-18-52 \mathrm{~N}$ & $139-21-55 \mathrm{E}$ & M.coccopoma, M.rosa, B.trigonus \\
\hline 2004.11 .30 & 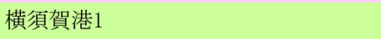 & 灯浮標 & 堀越·岡本 & $35-18-34 \mathrm{~N}$ & $139-41-25 \mathrm{E}$ & M.coccopoma \\
\hline 2008.09 .10 & 東京湾浮標 横須賀港1 & 灯浮標 & 山口ほか & $35-18-34 \mathrm{~N}$ & $139-41-25 \mathrm{E}$ & M.coccopoma \\
\hline 2009.12 .17 & 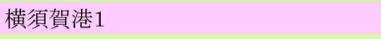 & 灯浮標 & 山口 & $35-18-34 \mathrm{~N}$ & $139-41-25 \mathrm{E}$ & M.coccoopoma, M.rosa, B.trigonus \\
\hline 2009.12 .28 & 由比ヶ浜 鎌倉 & 灯浮標 & 山口 & $35-18-30 \mathrm{~N}$ & $139-32-02 \mathrm{E}$ & M.coccopoma \\
\hline 2009.11 .02 & 浦が水道中央5号 & 灯浮標 & 山口 & $35-18-28 \mathrm{~N}$ & $139-43-56 \mathrm{E}$ & Cht.challengeri, M.rosa, A.amphitrite, A. sp. \\
\hline 2008.08 .28 & 東京湾浮標 横須賀港3 & 灯浮標 & 山口ほか & $35-18-18 \mathrm{~N}$ & $139-40-17 \mathrm{E}$ & M.соссорота \\
\hline 2008.08 .28 & 東京湾浮標＼cjkstart横須賀港5 & 灯浮標 & 山口ほか & $35-18-17 \mathrm{~N}$ & $139-39-44 \mathrm{E}$ & M.coccopoma \\
\hline 2004.11 .30 & 横須賀港6 & 灯浮標 & 堀越·岡本 & $35-18-14 \mathrm{~N}$ & $139-39-30 \mathrm{E}$ & M.coccopoma \\
\hline 2008.09.10 & 東京湾浮標＼cjkstart横須賀港4 & 灯浮標 & 山口ほか & $35-18-14 \mathrm{~N}$ & $139-39-30 \mathrm{E}$ & М.соссорота \\
\hline
\end{tabular}


Table 1. Continued.

\begin{tabular}{|c|c|c|c|c|c|c|}
\hline 日付 & 産地 & 付着物 & 採集者 & 緯度 & 経度 & 共存 \\
\hline 2009.12.22 & 第二海保南東方 & 灯浮標 & 山ロ & $35-18-09 \mathrm{~N}$ & $139-45-16 \mathrm{E}$ & $\begin{array}{l}\text { M.coccopoma, Cht.challengeri, T.japonica, } \\
\text { A.improvisus, M.rosa, B.trigonus }\end{array}$ \\
\hline 2009.09 .02 & 江ノ島湘南港 & 浮き栈橋 & 山口・植田 & $35-18-03 \mathrm{~N}$ & $139-29-06 \mathrm{E}$ & M.coccopoma, B.trigonus, A.amphitrite, A.improvisus \\
\hline 2008.09 .05 & 神奈川 江/島湘南港 & 灯浮標 & 植田育男 & $35-18-02 \mathrm{~N}$ & $139-29-06 \mathrm{E}$ & M.coccopoma \\
\hline 2009.04 .28 & 神奈川県藤沢市江/島 & 灯浮標 & 植田 & $35-18-02 \mathrm{~N}$ & $139-29-07 \mathrm{E}$ & M.coccopoma, M.rosa \\
\hline 2008.09.18 & 東京湾浮標 横須賀港南2 & 灯浮標 & 山口ほか & $35-17-56 \mathrm{~N}$ & $139-41-27 \mathrm{E}$ & M.coccopoma \\
\hline 2009.12.16 & 横須賀港南2 & 灯浮標 & 山口 & $35-17-56 \mathrm{~N}$ & $139-41-27 \mathrm{E}$ & M.coccopoma, M.rosa, B.trigonus \\
\hline 2009.11.16 & 大磯漁港 & 漁網 & 山口 & $35-17-55 \mathrm{~N}$ & $139-18-59 \mathrm{E}$ & М.соссорота \\
\hline 2009.12 .28 & 小坪漁港 逗子 & 灯浮標 & 山ロ & $35-17-44 \mathrm{~N}$ & $139-33-27 \mathrm{E}$ & M.coccopoma, A.amphitrite, B.trigonus, F.albicostatus \\
\hline 2008.07 .28 & 東京湾浮標 横須賀港南1 & 灯浮標 & 山口ほか & $35-17-31 \mathrm{~N}$ & $139-42-01 \mathrm{E}$ & M.coccopoma, M.rosa \\
\hline 2009.12 .16 & 横須賀港南1 ～～～～～～～～ & 灯浮標 & 山口 & $35-17-31 \mathrm{~N}$ & $139-42-01 \mathrm{E}$ & $\begin{array}{l}\text { M.coccopoma, M.rosa, B.trigonus, A.amphitrite, } \\
\text { Cht.challengeri }\end{array}$ \\
\hline 2008.09 .18 & 東京湾浮標 横須賀港南3 & 灯浮標 & 山口ほか & $35-17-25 \mathrm{~N}$ & $139-41-33 \mathrm{E}$ & M.coccopoma \\
\hline 2009.09 .05 & 横須賀港南5 & 灯浮標 & 山田 & $35-17-14 \mathrm{~N}$ & $139-41-19 \mathrm{E}$ & M.coccopoma, M.rosa, B.trigonus, A.amphitrite \\
\hline 2009.09 .03 & 浦賀水道航路中央3 & 灯浮標 & 山田 & $35-16-24 \mathrm{~N}$ & $139-45-42 \mathrm{E}$ & M.coccopoma, M.rosa, B.trigonus, A.amphitrite \\
\hline 2009.12 .28 & 真名瀬漁港 葉山 & 灯浮標 & 山口 & $35-16-08 \mathrm{~N}$ & 139-34-11 E & M.coccopoma, B.trigonus \\
\hline 2004.01 .06 & 浦賀水道航路4 & 灯浮標 & $\begin{array}{l}\text { 堀越彩香·岡 } \\
\text { 本研 }\end{array}$ & $35-15-22 \mathrm{~N}$ & $139-47-09 \mathrm{E}$ & M.coccopoma \\
\hline 2009.01 .07 & 東京湾浮標＼cjkstart浦賀水道航路4 & 灯浮標 & 山口ほか & $35-15-22 \mathrm{~N}$ & 139-47-09 E & M.coccopoma, M.rosa \\
\hline 2009.08 .26 & 浦賀水道航路中央2 & 灯浮標 & 木内 & $35-15-22 \mathrm{~N}$ & $139-46-35 \mathrm{E}$ & M.coccopoma, B.trigonus \\
\hline 2009.08 .27 & 浦賀水道航路3 & 灯浮標 & 木内 & $35-15-22 \mathrm{~N}$ & $139-46-00 \mathrm{E}$ & M.coccopoma, B.trigonus \\
\hline 2012.06.15-1 & 千葉県大原漁港浮きいけすのフロート & 漁具 & 山口 & $35-15-14.38 \mathrm{~N}$ & $140-24-12.51 \mathrm{E}$ & M.coccopoma \\
\hline 2009.12.28 & 久留和漁港 ～～～～～～ & 灯浮標 & 山口 & $35-14-43 \mathrm{~N}$ & $139-35-31 \mathrm{E}$ & M.coccopoma \\
\hline 2009.11.16 & 久留和海岸 & 漁網 & 植田 & $35-14-42 \mathrm{~N}$ & $139-35-32 \mathrm{E}$ & M.coccopoma \\
\hline 2009.11 .16 & 小田原漁港 & 漁網 & 山口 & $35-14-20 \mathrm{~N}$ & $139-08-56 \mathrm{E}$ & M.соссорота \\
\hline 2009.02 .26 & 香山根灯浮標 & 灯浮標 & 山口ほか & $35-14-17 \mathrm{~N}$ & $139-44-42 \mathrm{E}$ & M.coccopoma, M.rosa \\
\hline 2009.12 .25 & 香山根 10ヶ月前に浸漬したもの & 灯浮標 & 山口 & $35-14-17 \mathrm{~N}$ & $139-44-42 \mathrm{E}$ & M.coccopoma, M.rosa, B.trigonus \\
\hline 2009.12 .14 & 横須賀市佐島 大楠漁協佐島支所 & 漁網 & 山口 & $35-13-22 \mathrm{~N}$ & $139-36-32 \mathrm{E}$ & M.coccopoma, M.rosa, B.trigonus \\
\hline 2009.12 .25 & 久里浜大津根 ～～～～～～～ & 灯浮標 & 山口 & $35-13-15 \mathrm{~N}$ & $139-43-51 \mathrm{E}$ & M.coccopoma, M.rosa, B.trigonus \\
\hline 2005.05 .01 & 浦賀水道航路1 & 灯浮標 & 堀越·岡本 & $35-12-43 \mathrm{~N}$ & $139-46-02 \mathrm{E}$ & M.coccopoma \\
\hline 2009.02 .26 & 東京湾浮標 浦賀水道航路1 & 灯浮標 & 山口ほか & $35-12-43 \mathrm{~N}$ & $139-46-02 \mathrm{E}$ & M.coccopoma \\
\hline 2009.05 .19 & 東京湾浮標 浦賀1 & 灯浮標 & $\begin{array}{l}\text { 山田・木内・山 } \\
\text { 口・深町みどり }\end{array}$ & $35-12-43 \mathrm{~N}$ & $139-46-02 \mathrm{E}$ & M.coccopoma, M.rosa \\
\hline 2009.09 .04 & 浦賀水道航路2 & 灯浮標 & 山田 & $35-12-43 \mathrm{~N}$ & $139-47-11 \mathrm{E}$ & M.coccopoma, M.rosa, B.trigonus \\
\hline 2009.08 .19 & 笠島 & 灯浮標 & 山口 & $35-12-40 \mathrm{~N}$ & $139-44-20 \mathrm{E}$ & M.coccopoma, M.rosa \\
\hline 2008.06 .21 & 神奈川 横須賀長井 & 漁網 & 植田・山口 & $35-12-21 \mathrm{~N}$ & $139-36-38 \mathrm{E}$ & M.coccopoma \\
\hline 2009.11.16 & 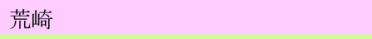 & 漁網 & 植田 & $35-11-49 \mathrm{~N}$ & $139-36-08 \mathrm{E}$ & M.coccopoma \\
\hline 2009.12.28 & 初声漁港 & 灯浮標 & 山口 & $35-10-18 \mathrm{~N}$ & $139-37-06 \mathrm{E}$ & M.coccopoma, A.amphitrite, B.trigonus, A.improvisus \\
\hline 2009.10 .15 & 相模網代埼沖 & 灯浮標 & 山ロ & $35-10-12 \mathrm{~N}$ & $139-35-48 \mathrm{E}$ & M.соссорота \\
\hline 2009.11 .09 & 真鶴岩漁港沖 定置網 & 漁網 & 山口 & $35-09-47 \mathrm{~N}$ & $139-08-48 \mathrm{E}$ & $\begin{array}{l}\text { M.coccopoma, M.rosa, B.trigonus Rocky shore: } \\
\text { T.japonica }\end{array}$ \\
\hline 2007.12 .08 & 千葉 鋸南町明鐘崎 & 漁網 & 菊地麻衣 & $35-09-15 \mathrm{~N}$ & $139-49-13 \mathrm{E}$ & M.соссорота \\
\hline 2009.11 .09 & 真鶴港沖 定置網 & 漁網 & 山口 & $35-09-10 \mathrm{~N}$ & 139-09-07 E & M.coccopoma, M.rosa, B.trigonus \\
\hline 2009.02 .25 & 三崎港 釜根灯浮標 & 灯浮標 & 山口ほか & $35-08-28 \mathrm{~N}$ & $139-36-19 \mathrm{E}$ & M.coccopoma, M.rosa, M.volcano \\
\hline 2009.10 .16 & 三崎港東口第2号 & 灯浮標 & 山口 & $35-08-09 \mathrm{~N}$ & $139-37-54 \mathrm{E}$ & M.coccopoma \\
\hline 2009.10 .16 & 三崎港東口第1号 & 灯浮標 & 山口 & $35-08-00 \mathrm{~N}$ & $139-37-47 \mathrm{E}$ & M.coccopoma \\
\hline 2009.05 .26 & 千葉県鴨川市小湊実験所 & 岩礁 & 山口・木内 & $35-07-11 \mathrm{~N}$ & 140-11-07 E & M.coccopoma, M.rosa \\
\hline 2008.04 .11 & 千葉 南房総岩井 高崎 & 漁網 & 山ロ & $35-04-54 \mathrm{~N}$ & $139-50-25 \mathrm{E}$ & M.coccopoma, M.rosa \\
\hline 2005.05 .11 & 千葉 南房総小浦 & 漁網 & 周藤拓歩 & $35-04-42 \mathrm{~N}$ & $139-50-13 \mathrm{E}$ & M.coccopoma \\
\hline 2009.10 .30 & 富浦沖 & 灯浮標 & 山口 & $35-03-54 \mathrm{~N}$ & $139-47-50 \mathrm{E}$ & M.coccopoma, B.trigonus, M.rosa, T.japonica \\
\hline 2009.07.29 & 沼津市静浦漁港 & ロープ & 植田・山口 & $35-03-27 \mathrm{~N}$ & $138-52-43 \mathrm{E}$ & M.coccopoma, M.rosa \\
\hline 2009.04 .20 & 静岡県沼津内浦漁港生簣 & 灯浮標 & 植田 & $35-01-21 \mathrm{~N}$ & $138-53-50 \mathrm{E}$ & M.coccopoma, M.rosa \\
\hline 2009.07 .29 & 沼津市内浦漁港 生筫 & ロープ & 植田・山口 & $35-01-21 \mathrm{~N}$ & $138-53-50 \mathrm{E}$ & M.coccopoma, M.rosa \\
\hline 2011.11.22-1 & 千葉県金谷漁港 & 漁具 & 山口 & $35-9-57.35 \mathrm{~N}$ & $139-49-18.90 \mathrm{E}$ & M.coccopoma, L. sp., A.amphitrite \\
\hline 2013.11 .20 & 静岡県富士市田子の浦港 & 漁具 & 山口 & $35-8-17.90 \mathrm{~N}$ & $138-41-31.08 \mathrm{E}$ & \\
\hline 2011.11.22-2 & 千葉県保田漁港 & 漁具 & 山口 & $35-7-52.63 \mathrm{~N}$ & $139-50-14.42 \mathrm{E}$ & M.coccopoma, M.rosa (rare) \\
\hline 2011.07.02 & 千葉県勝浦市浜行川漁港外 & 岩礁 & 大和田正人 & $35-7-17.4 \mathrm{~N}$ & 140-14-19.4 E & M.coccopoma, M.volcano, M.rosa \\
\hline 2011.11.22-3 & 千葉県勝山漁港 & 漁具 & 山口 & $35-7-17.12 \mathrm{~N}$ & $139-49-54.02 \mathrm{E}$ & M.coccopoma, M.rosa (rare) \\
\hline 2013.11 .20 & 静岡県静岡市清水区由比港 & 漁具 & 山口 & $35-5-57.03 \mathrm{~N}$ & 138-33-18 E & \\
\hline 2011.12.13-03 & 千葉県鴨川市鴨川漁港 & 漁具 & 山口 & $35-5-30.52 \mathrm{~N}$ & $140-6-29.85 \mathrm{E}$ & M.сосcopoma \\
\hline 2011.10.29- & 静岡県熱海市 & 漁具 & 山口 & $35-5-20.10 \mathrm{~N}$ & $139-4-41.04 \mathrm{E}$ & M.coccopoma \\
\hline 2008.04.11 & 千葉県南房総市高崎 高崎漁港 & 漁具 & 山口 & $35-4-54.02 \mathrm{~N}$ & $139-50-25.58 \mathrm{E}$ & M.coccopoma, M.rosa (rare) \\
\hline 2011.11.22-4 & 千葉県高崎漁港 & 漁具 & 山口 & $35-4-52.80 \mathrm{~N}$ & $139-50-26.18 \mathrm{E}$ & M.coccopoma, M.rosa (rare) \\
\hline 2011.12.13-02 & 千葉県南房総市和田漁港 & 漁具 & 山口 & $35-2-7.68 \mathrm{~N}$ & $140-0-52.87 \mathrm{E}$ & M.coccopoma, M.rosa, B.trigonus \\
\hline $2011.10 .29-$ & 網代港 ～～～～～～～～～～～ & 漁具 & 山口 & $35-2-46.65 \mathrm{~N}$ & 139- 5-18.89 E & M.coccopoma, M.rosa \\
\hline 2011.11.22-5 & 千葉県富浦漁港 & 漁具 & 山口 & $35-2-16.77 \mathrm{~N}$ & $139-49-19.16 \mathrm{E}$ & М.соссорота \\
\hline 2011.10.31- & 沼津市西浦立保 & 漁具 & 山口 & $35-0-58.52 \mathrm{~N}$ & $138-51-3.47 \mathrm{E}$ & M.coccopoma, M.rosa \\
\hline 2011.11.22-7 & 千葉県洲崎漁港 & 漁具 & 山口 & $34-58-30.79 \mathrm{~N}$ & $139-45-38.27 \mathrm{E}$ & M.coccopoma \\
\hline 2011.11.22-6 & 千葉県館山休昵村 & 漁具 & 山ロ & $34-58-23.98 \mathrm{~N}$ & $139-47-37.51 \mathrm{E}$ & M.coccopoma \\
\hline
\end{tabular}


Table 1. Continued.

\begin{tabular}{|c|c|c|c|c|c|c|}
\hline 日付 & 産地 & 付着物 & 採集者 & 緯度 & 経度 & 共存 \\
\hline $2011.10 .31-$ & 沼津市戸田港 & 漁具 & 山口 & $34-58-21.13 \mathrm{~N}$ & $138-45-49.97 \mathrm{E}$ & M.coccopoma, M.rosa \\
\hline 2011.10.29- & 伊東市川奈漁港 & 漁具 & 山口 & $34-57-5.29 \mathrm{~N}$ & 139- 8-5.36 E & М.соссорота \\
\hline 2013.11 .20 & 静岡県用宗港 & 漁具 & 山口 & $34-55-29.29 \mathrm{~N}$ & $138-22-4.06 \mathrm{E}$ & \\
\hline 2011.12.13-01 & 千葉県南房総市名倉漁港 & 漁具 & 山口 & $34-54-27.89 \mathrm{~N}$ & $139-54-40.88 \mathrm{E}$ & M.coccopoma, M.volcano, B.trigonus \\
\hline 2010.04 .11 & 伊東市富戸漁港 ～～～～～ & 漁具 & 山口 & $34-53-42 \mathrm{~N}$ & $139-8-12 \mathrm{E}$ & M.coccopoma \\
\hline 2013.11.20-01 & 静岡県焼津市小川(こがわ) 港 & 漁具 & 山口 & $34-51-8.64 \mathrm{~N}$ & $138-19-31.24 \mathrm{E}$ & M.coccopoma, M.rosa \\
\hline 2011.10.31- & 伊豆赤沢漁港 ～～～～～～ & 漁具 & 山口 & $34-51-26.90 \mathrm{~N}$ & $139-5-26.38 \mathrm{E}$ & M.coccopoma, M.rosa \\
\hline 2013.11.21 & 静岡県大井川港 & 漁具 & 山口 & $34-47-0.76 \mathrm{~N}$ & $138-17-41.42 \mathrm{E}$ & \\
\hline 2009.11 .17 & 網干2 & 灯浮標 & 山口・大谷 & $34-46-3 \mathrm{~N}$ & $134-36-35 \mathrm{E}$ & $\begin{array}{l}\text { M.rosa, B.trigonus, A.ebruneus, A.improvisus, } \\
\text { A.amphitrite }\end{array}$ \\
\hline 2009.07 .30 & 広畑航路6 & 灯浮標 & 大谷 & $34-45-9 \mathrm{~N}$ & $134-37-30 \mathrm{E}$ & M.rosa \\
\hline 2009.07 .30 & 飾磨航路1 & 灯浮標 & 大谷 & $34-45-8 \mathrm{~N}$ & $134-38-55 \mathrm{E}$ & M.rosa \\
\hline 2011.10.31- & 伊豆河津今井海岸 & 漁具 & 山口 & $34-45-14.80 \mathrm{~N}$ & $139-0-54.47 \mathrm{E}$ & M.coccopoma, M.rosa \\
\hline 2011.10.31- & 伊豆河津町浜 苔蒲沢海岸 & 漁具 & 山口 & $34-43-3.72 \mathrm{~N}$ & $138-59-29.55 \mathrm{E}$ & M.coccopoma, M.rosa \\
\hline 1999 & 三河湾佐久島（情報） & 岩礁 & 西川輝明 & $34-42-54 \mathrm{~N}$ & 137-03-09 E & M.coccopoma \\
\hline 2013.11.21-1 & 静岡県相良平田港 & 漁具 & 山口 & $34-42-2.78 \mathrm{~N}$ & $138-12-49.61 \mathrm{E}$ & M.coccopoma, B.trigonus \\
\hline 2009.07.15 & 神戸灘東 & 灯浮標 & 大谷 & $34-41-47 \mathrm{~N}$ & $135-15-0 \mathrm{E}$ & \\
\hline 2009.08 .04 & 東播磨航路5 & 灯浮標 & 大谷 & $34-41-26 \mathrm{~N}$ & $134-49-32 \mathrm{E}$ & M.rosa \\
\hline 2013.11.21-2 & 静岡県相良港 & 漁具 & 山口 & $34-41-14.27 \mathrm{~N}$ & $138-12-28.20 \mathrm{E}$ & M.coccopoma, M.rosa \\
\hline 2007.03.20 & 静岡県賀茂郡南伊豆町千曽敷 & 岩礁 & 山口 & $34-40-49 \mathrm{~N}$ & $138-45-57 \mathrm{E}$ & M.coccopoma, M.volcano \\
\hline $2014.04 .12-2$ & 静岡県浜松市舞阪町舞阪 & 漁具 & 山口 & $34-40-48.50 \mathrm{~N}$ & $137-36-13.34 \mathrm{E}$ & \\
\hline 2009.07.24 & 神戸港灘2 & 灯浮標 & 山口 & $34-40-46 \mathrm{~N}$ & $135-14-17 \mathrm{E}$ & M.rosa \\
\hline 2009.07 .15 & 神戸灘1 & 灯浮標 & 大谷 & $34-40-46 \mathrm{~N}$ & $135-14-37 \mathrm{E}$ & \\
\hline 2010.0105 & Jamstecよこすか船底@神戸 & 船底 & 山口 & $34-40-35 \mathrm{~N}$ & $135-11-09 \mathrm{E}$ & $\begin{array}{l}\text { M.coccopoma, A.amphitrite, Lepas sp., } \\
\text { B.zhujiangensis ?, B.trigonus }\end{array}$ \\
\hline 2013.11.21-4 & 静岡県袋井市福田漁港 & 漁具 & 山口 & $34-40-18.36 \mathrm{~N}$ & $137-54-29.65 \mathrm{E}$ & \\
\hline 2007.03.22 & 静岡県下田市鍋田湾 & ブイ & 山口 & $34-39-56 \mathrm{~N}$ & $138-56-17 \mathrm{E}$ & M.coccopoma, M.rosa \\
\hline 2009.11.17 & 播磨灘北9 & 灯浮標 & 山口・大谷 & $34-39-4 \mathrm{~N}$ & $134-42-3 \mathrm{E}$ & $\begin{array}{l}\text { M.rosa, B.trigonus, B.zhujiangensis ?, A.ebruneus, } \\
\text { A.improvisus, Cht.challengeri, T.japonica, }\end{array}$ \\
\hline 2011.04.18 & 下田市須崎 恵比須島南西岸 低潮線 & 岩礁 & 山口 & $34-39-3.17 \mathrm{~N}$ & $138-57-49.94 \mathrm{E}$ & M.coccopoma, M.volcano, M.rosa \\
\hline 2013.05 .26 & 下田市須崎 恵比須島南西岸 低潮線 & 岩礁 & 山口 & $34-39-2.66 \mathrm{~N}$ & $138-57-50.31 \mathrm{E}$ & M.coccopoma (juveniles), M.volcano, T.japonica \\
\hline 2009.08 .04 & 播磨灘北航路10 & 灯浮標 & 大谷 & $34-38-27 \mathrm{~N}$ & $134-49-04 \mathrm{E}$ & M.coccopoma, M.rosa \\
\hline 2013.11.21-3 & 静岡県牧之原市地頭方漁港 & 漁具 & 山口 & $34-37-50.85 \mathrm{~N}$ & $138-11-55.48 \mathrm{E}$ & M.coccopoma \\
\hline 2009.07 .16 & 平磯 & 灯浮標 & 山口 & $34-37-21 \mathrm{~N}$ & $135-3-34 \mathrm{E}$ & \\
\hline 2014.04.12-1 & 愛知県田原市赤羽根漁港 & 漁具 & 山口 & $34-36-30.87 \mathrm{~N}$ & $137-11-14.46 \mathrm{E}$ & M.coccopoma \\
\hline 2009.07.24 & 神戸港沖2 ～～～～～～～～～～～～ & 灯浮標 & 山口 & $34-35-39 \mathrm{~N}$ & $135-14-20 \mathrm{E}$ & M.coccopoma, M.rosa \\
\hline 2009.07 .17 & 堺航路13 & 灯浮標 & 大谷 & $34-35-33 \mathrm{~N}$ & $135-25-33 \mathrm{E}$ & \\
\hline 2009.07 .17 & 堺航路14 & 灯浮標 & 大谷 & $34-35-27 \mathrm{~N}$ & $135-25-27 \mathrm{E}$ & \\
\hline 2009.07 .16 & 神戸港沖1 & 灯浮標 & 山口 & $34-35-26 \mathrm{~N}$ & $135-11-12 \mathrm{E}$ & M.coccopoma \\
\hline 2009.07 .31 & 泉北南6 & 灯浮標 & 大谷 & $34-32-6 \mathrm{~N}$ & $135-23-44 \mathrm{E}$ & \\
\hline 2009.09 .16 & 新日鵬@水岛港 & 船底 & 羽生田岳昭 & $34-29-23 \mathrm{~N}$ & $133-44-07 \mathrm{E}$ & M.coccopoma, A.variegatus, A. sp., B.zhujiangensis? \\
\hline 2010.05 .21 & 小豆島 草壁栈橋 & 浮き栈橋 & 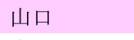 & $34-28-45 \mathrm{~N}$ & $134-17-52 \mathrm{E}$ & M.coccopoma, M.rosa, B.trigonus \\
\hline 2009.07 .31 & 泉佐野航路3 & 灯浮標 & 大谷 & $34-26-47 \mathrm{~N}$ & $135-19-14 \mathrm{E}$ & M.rosa \\
\hline 2009.12 .03 & 深日第一 & 灯浮標 & 大谷 & $34-19-38 \mathrm{~N}$ & $135-08-24 \mathrm{E}$ & M.coccopoma \\
\hline 2009.12.03 & 深日第二 & 灯浮標 & 大谷 & $34-19-25 \mathrm{~N}$ & $135-08-13 \mathrm{E}$ & M.coccopoma \\
\hline 2009.07 .25 & 和歌山加太城ヶ崎 & 岩礁 & 山口 & $34-17-09 \mathrm{~N}$ & $135-04-06 \mathrm{E}$ & M.coccopoma, M.rosa \\
\hline 2009.07 .24 & 備後灘航路4（瀬戸内海西部） & 灯浮標 & 大谷 & $34-13-54 \mathrm{~N}$ & $133-20-15 \mathrm{E}$ & M.coccopoma, M.rosa, B.trigonus \\
\hline 2009.07 .24 & 備後灘航路3（瀬戸内海西部） & 灯浮標 & 大谷 & $34-12-37 \mathrm{~N}$ & $133-15-12 \mathrm{E}$ & M.coccopoma, M.rosa, B.trigonus, Chi.amaryllis \\
\hline 1981.12.22 & 海南発電所 テスト板10/16〜12/22 & 岩礁 & 大谷道夫 & $34-08-55 \mathrm{~N}$ & $135-11-22 \mathrm{E}$ & M.coccopoma \\
\hline 2009.07 .14 & 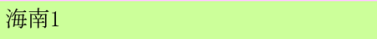 & 灯浮標 & 大谷 & $34-08-48 \mathrm{~N}$ & $135-09-42 \mathrm{E}$ & M.coccopoma, M.rosa \\
\hline 2009.07 .28 & 海南3号 & 灯浮標 & 大谷 & $34-08-48 \mathrm{~N}$ & $135-10-20 \mathrm{E}$ & M.coccopoma, M.rosa \\
\hline 2009.07 .14 & 海南2 & 灯浮標 & 大谷 & $34-08-42 \mathrm{~N}$ & $135-09-42 \mathrm{E}$ & M.coccopoma, M.rosa, B.trigonus \\
\hline 2009.07 .28 & 海南4号 & 灯浮標 & 大谷 & $34-08-41 \mathrm{~N}$ & $135-10-20 \mathrm{E}$ & M.coccopoma, M.rosa \\
\hline 2009.07 .06 & 関門31 & 灯浮標 & 山口 & $33-58-29.2 \mathrm{~N}$ & $130-58-38.4 \mathrm{E}$ & M.rosa \\
\hline 2009.07 .07 & 宇部港8 & 灯浮標 & 山口 & $33-55-39.7 \mathrm{~N}$ & $131-13-33.9 \mathrm{E}$ & M.rosa \\
\hline 2009.11 .20 & 下関南東水道2 & 灯浮標 & 山口 & $33-55-38 \mathrm{~N}$ & $131-4-58 \mathrm{E}$ & \\
\hline 2009.07 .06 & 若松10 & 灯浮標 & 山口 & $33-55-27 \mathrm{~N}$ & $130-49-15 \mathrm{E}$ & M.rosa \\
\hline 2009.07 .07 & 宇部港本山4 & 灯浮標 & 山口 & $33-55-04.2 \mathrm{~N}$ & $131-11-52.7 \mathrm{E}$ & M.rosa \\
\hline 2009.11 .19 & 若松16 & 灯浮標 & 山口 & $33-54-37 \mathrm{~N}$ & 130-49-1 E & B.trigonus, A. sp., A.ebruneus \\
\hline 2009.11 .18 & 関門24 & 灯浮標 & 山口 & $33-54-30 \mathrm{~N}$ & $130-55-45 \mathrm{E}$ & M.rosa, A.variegatus, Chi.amaryllis, B.trigonus \\
\hline 2009.11.19 & 若松17 & 灯浮標 & 山口 & $33-53-28 \mathrm{~N}$ & $130-48-19 \mathrm{E}$ & B.trigonus, A. sp., A.ebruneus \\
\hline 2009.04 .16 & 伊予灘航路8号 & 灯浮標 & 山口•大谷 & $33-49-53 \mathrm{~N}$ & $132-32-35 \mathrm{E}$ & M.coccopoma, M.rosa \\
\hline 2009.11 .18 & 荻田港9 & 灯浮標 & 山口 & $33-48-7 \mathrm{~N}$ & $131-1-39 \mathrm{E}$ & M.rosa, B.trigonus, A.amphitrite, A.variegatus \\
\hline 2009.11.20 & 荻田港7 & 灯浮標 & 山口 & $33-48-20 \mathrm{~N}$ & $131-2-18 \mathrm{E}$ & \\
\hline 2009.07 .09 & 田辺港アボセ灯浮標 & 灯浮標 & 大谷 & $33-43-08 \mathrm{~N}$ & $135-21-11 \mathrm{E}$ & M.coccopoma, M.rosa, B.trigonus, B.rostratus \\
\hline 2009.07.09 & 田辺港キヌガサ灯浮標 & 灯浮標 & 大谷 & $33-43-04 \mathrm{~N}$ & $135-22-24 \mathrm{E}$ & M.coccopoma, M.rosa \\
\hline 2005.03 .11 & 和歌山県白浜町田辺湾塔島 & 岩礁 & 山口寿之 & $33-41-48 \mathrm{~N}$ & $135-20-05 \mathrm{E}$ & M.coccopoma \\
\hline 2007.09 .23 & 和歌山県白浜町田辺湾塔島 & 岩礁 & 山口 & $33-41-48 \mathrm{~N}$ & $135-20-05 \mathrm{E}$ & $\begin{array}{l}\text { M.coccopoma, M.volcano } \\
\text { M.coccopoma, M.volcano, M.rosa, T.japonica, }\end{array}$ \\
\hline
\end{tabular}


Table 1. Continued.

\begin{tabular}{|c|c|c|c|c|c|c|}
\hline 日付 & 産地 & 付着物 & 採集者 & $\begin{array}{l}\text { 緯度 } \\
\end{array}$ & 経度 & 共存 \\
\hline $2011.07 .03-01$ & 1 和歌山県白浜町 瀬戸臨海塔島 & 岩礁 & 山口 & $33-41-47.23 \mathrm{~N}$ & $135-20-3.40 \mathrm{E}$ & $\begin{array}{l}\text { T.formosana, T.squamosa, Capitulum.mitella, } \\
\text { Cht.challengeri, }\end{array}$ \\
\hline 2011.08.28-06 & 6 高知県手結漁港 & 定置網 & 山口 & $33-31-47.36 \mathrm{~N}$ & $133-45-22.20 \mathrm{E}$ & M.coccopoma \\
\hline 2011.08.28-07 & 7 高知県漁協手結支店 & 定置網 & 山口 & $33-31-41.38 \mathrm{~N}$ & $133-45-17.82 \mathrm{E}$ & M.coccopoma \\
\hline 2011.07 .02 & 和歌山県すさみ町黒崎 & 岩礁 & 山口 & $33-31-4.60 \mathrm{~N}$ & $135-32-7.35 \mathrm{E}$ & $\begin{array}{l}\text { M.coccopoma, M.volcano, T.japonica, T.formosana, } \\
\text { T.squamosa, Capitulum mitella, Cht.challengeri }\end{array}$ \\
\hline 2011.08.28-08 & 8 高知県安田漁港 & 定置網 & 山口 & $33-26-33.87 \mathrm{~N}$ & $133-57-33.62 \mathrm{E}$ & M.coccopoma, M.volcano, M.rosa \\
\hline 2011.08.28-09 & 9 高知県奈半利漁港 & 定置網 & 山口 & $33-25-21.51 \mathrm{~N}$ & $134-1-5.49 \mathrm{E}$ & M.coccopoma, M.volcano, M.rosa \\
\hline 2011.08.27-01 & 1 高知県土佐新荘漁港 & 定置網 & 山口 & $33-23-4.42 \mathrm{~N}$ & $133-16-46.16 \mathrm{E}$ & М.соссорота \\
\hline 2011.08.29-05 & 5 高知県佐喜浜漁港 & 定置網 & 山口 & $33-23-35.58 \mathrm{~N}$ & $134-12-36.62 \mathrm{E}$ & M.coccopoma, M.volcano, M.rosa \\
\hline 2011.08.28-10 & 0 高知県加領郷漁港 & 定置網 & 山口 & $33-22-49.65 \mathrm{~N}$ & $134-2-7.94 \mathrm{E}$ & M.coccopoma \\
\hline 2012.10 .25 & 平戸市春日町字呼崎·生月大橋橋脚 & 橋脚 & 勝山一朗 & $33-21-13.25 \mathrm{~N}$ & $129-26-12.60 \mathrm{E}$ & B.trigonus, M.rosa \\
\hline 2011.08.29-04 & 4 高知県椎名漁港 & 定置網 & 山口 & $33-19-35.01 \mathrm{~N}$ & $134-11-48.70 \mathrm{E}$ & M.coccopoma, M.volcano, M.rosa \\
\hline 2011.08.27-02 & 2 高知県久礼漁港 & 定置網 & 山口 & $33-19-22.22 \mathrm{~N}$ & $133-14-9.26 \mathrm{E}$ & M.соссорота \\
\hline 2011.08.29-03 & 3 高知県三津漁港 & 定置網 & 山口 & $33-17-43.14 \mathrm{~N}$ & $134-11-16.35 \mathrm{E}$ & M.coccopoma, M.volcano, M.rosa \\
\hline 2011.08.28-11 & 1 高知県室津漁港 & 定置網 & 山口 & $33-16-54.19 \mathrm{~N}$ & 134- 9-7.58 E & M.соссорота \\
\hline 2011.08.27-03 & 3 高知県上の加江漁港 & 定置網 & 山口 & $33-16-29.80 \mathrm{~N}$ & $133-14-33.32 \mathrm{E}$ & M.соссорота \\
\hline 2011.08.29-01 & 1 高知県室戸岬新港 & 定置網 & 山口 & $33-15-51.17 \mathrm{~N}$ & $134-9-49.55 \mathrm{E}$ & M.coccopoma, M.volcano, M.rosa \\
\hline 2011.08.29-02 & 2 高知県高岡漁港 & 定置網 & 山口 & $33-15-34.60 \mathrm{~N}$ & $134-11-2.95 \mathrm{E}$ & M.coccopoma, M.volcano, M.rosa \\
\hline 2009.06.09 & $\begin{array}{l}\text { 干切瀬沖灯浮標 肥前丸尾港(南松浦郡 } \\
\text { 新上五島町) }\end{array}$ & 灯浮標 & 山口 & $33-00-20 \mathrm{~N}$ & $129-05-57 \mathrm{E}$ & M.rosa \\
\hline 2011.08.28-05 & 5 高知県土佐佐賀漁港 & 定置網 & 山口 & $33-4-39.44 \mathrm{~N}$ & $133-6-27.96 \mathrm{E}$ & M.coccopoma, M.rosa \\
\hline 2011.08.28-04 & 4 高知県土佐上川口漁港 & 定置網 & 山口 & $33-2-20.43 \mathrm{~N}$ & $133-3-29.18 \mathrm{E}$ & M.coccopoma, M.rosa \\
\hline 2011.08.28-03 & 3 高知県以布利漁港 海遊館分室東 & 定置網 & 山口 & $32-48-5.01 \mathrm{~N}$ & $132-57-47.93 \mathrm{E}$ & M.coccopoma, M.rosa \\
\hline 2011.08.28-02 & 2 高知県以布利漁港 & 定置網 & 山口 & $32-47-55.43 \mathrm{~N}$ & $132-57-54.63 \mathrm{E}$ & M.coccopoma, M.rosa \\
\hline 2009.05 .25 & 長崎県雲仙市千岩漁港 & 船揚場 & 坂口勇・植田 & $32-46-48.8 \mathrm{~N}$ & $130-11-35.7 \mathrm{E}$ & M.rosa \\
\hline 2009.06 .11 & 柱瀬灯浮標 五島市柱瀬 & 灯浮標 & 山口 & $32-46-21 \mathrm{~N}$ & $128-54-40 \mathrm{E}$ & M.rosa, M.volcano \\
\hline 2011.08.28-01 & 1 高知県土佐清水港 & 定置網 & 山口 & $32-46-19.25 \mathrm{~N}$ & $132-57-16.55 \mathrm{E}$ & M.coccopoma \\
\hline 2009.06 .11 & 金剛曽根灯浮標 赤八工鼻五島市北方 & 灯浮標 & 山口 & $32-45-25.3 \mathrm{~N}$ & $128-53-02 \mathrm{E}$ & M.rosa, M.volcano \\
\hline 2009.06 .09 & $\begin{array}{l}\text { センバイ瀬灯浮標 崎山鼻(五島市東南 } \\
\text { 東) }\end{array}$ & 灯浮標 & 山口 & $32-38-41 \mathrm{~N}$ & $128-56-22 \mathrm{E}$ & M.rosa, M.volcano \\
\hline 2010.03 .08 & 青島漁港(宮崎) & 漁具 & 山口 & $31-47-48 \mathrm{~N}$ & $131-28-17 \mathrm{E}$ & M.coccopoma \\
\hline 2010.03 .08 & 富浦漁港(宮崎) & 漁具 & 山口 & $31-38-47 \mathrm{~N}$ & $131-27-33 \mathrm{E}$ & M.coccopoma, M.volcano \\
\hline 2010.03 .10 & 南園漁港 & 漁具 & 山口 & $31-36-59 \mathrm{~N}$ & $130-47-45 \mathrm{E}$ & M.coccopoma, B.trigonus \\
\hline 2010.03 .10 & 深漁港 & 漁具 & 山口 & $31-35-57 \mathrm{~N}$ & $130-47-13 \mathrm{E}$ & M.coccopoma, B.trigonus \\
\hline 2010.03 .08 & 油津漁港(宮崎) & 漁具 & 山口 & $31-34-21 \mathrm{~N}$ & $131-23-59 \mathrm{E}$ & M.coccopoma \\
\hline 2010.03 .10 & 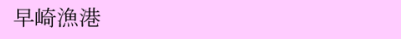 & 漁具 & 山口 & $31-33-28 \mathrm{~N}$ & $130-43-07 \mathrm{E}$ & M.coccopoma, B.trigonus \\
\hline 2010.03 .08 & 目井津漁港(宮崎) & 漁具 & 山口 & $31-32-25 \mathrm{~N}$ & $131-23-05 \mathrm{E}$ & M.coccopoma, M.rosa \\
\hline 2010.03.09 & 海潟漁港 ～～～～～～～～ & 漁具 & 山口 & $31-31-44 \mathrm{~N}$ & $130-41-54 \mathrm{E}$ & M.coccopoma, M.rosa, B.trigonus \\
\hline 2010.03 .09 & 垂水漁港 & 漁具 & 山口 & $31-29-47 \mathrm{~N}$ & $130-41-49 \mathrm{E}$ & М.coccopoma, M.rosa, B.trigonus \\
\hline 2010.03 .08 & 串間2(宮崎) & 漁具 & 山口 & $31-27-10 \mathrm{~N}$ & $131-12-10 \mathrm{E}$ & M.coccopoma, M.rosa \\
\hline 2010.03 .08 & 串間南方(宮崎) & 漁具 & 山口 & $31-26-42 \mathrm{~N}$ & $131-12-30 \mathrm{E}$ & M.coccopoma, M.rosa \\
\hline 2010.03 .09 & 古江漁港 & 漁具 & 山口 & $31-24-08 \mathrm{~N}$ & $130-45-55 \mathrm{E}$ & M.coccopoma, M.rosa, B.trigonus \\
\hline 2010.03 .09 & 高須漁港 & 漁具 & 山口 & $31-20-56 \mathrm{~N}$ & $130-47-36 \mathrm{E}$ & M.coccopoma, M.rosa, B.trigonus \\
\hline 2010.03 .09 & 東風泊漁港 & 漁具 & 山口 & $31-20-19 \mathrm{~N}$ & $131-04-12 \mathrm{E}$ & M.coccopoma, M.rosa, B.trigonus \\
\hline 2009.05 .21 & 東京湾浮標 浦賀5 & 灯浮標 & $\begin{array}{l}\text { 山田・木内・山 } \\
\text { 口 }\end{array}$ & $31-17-41 \mathrm{~N}$ & $139-44-01 \mathrm{E}$ & M.coccopoma, M.rosa \\
\hline 2010.03 .09 & 内之浦漁港 & 漁具 & 山口 & $31-16-32 \mathrm{~N}$ & $131-04-55 \mathrm{E}$ & M.coccopoma, M.rosa, B.trigonus \\
\hline 2010.03 .11 & 種子島 浦田漁港 & 漁具 & 山口 & $30-49-34 \mathrm{~N}$ & $131-02-51 \mathrm{E}$ & \\
\hline 2010.03 .11 & 種子島 伊関漁港 & 漁具 & 山口 & $30-49-29 \mathrm{~N}$ & $131-03-47 \mathrm{E}$ & \\
\hline 2010.03 .11 & 種子島 伊関漁港 & 漁具 & 山口 & $30-46-20 \mathrm{~N}$ & 131-04-31 E & \\
\hline 2010.03 .11 & 種子島 住吉漁港 & 漁具 & 山口 & $30-40-01 \mathrm{~N}$ & $130-56-42 \mathrm{E}$ & \\
\hline 2010.03 .11 & 種子島 牧川漁港 & 漁具 & 山口 & $30-37-40 \mathrm{~N}$ & 130-57-01 E & \\
\hline 2010.03 .11 & 種子島 浜津脇漁港 & 漁具 & 山口 & $30-36-03 \mathrm{~N}$ & $130-57-02 \mathrm{E}$ & \\
\hline 2010.03 .11 & 種子島 島間漁港 & 漁具 & 山口 & $30-27-50 \mathrm{~N}$ & $130-51-43 \mathrm{E}$ & B.zhujiangensis? \\
\hline 2010.03 .11 & 種子島 島問漁港 & 漁具 & 山口 & $30-27-47 \mathrm{~N}$ & $130-51-58 \mathrm{E}$ & \\
\hline 2010.03 .11 & 種子島 熊野漁港 & 漁具 & 山口 & $30-27-43 \mathrm{~N}$ & $130-58-3 \mathrm{E}$ & M.rosa, M.volcano \\
\hline 2010.03 .11 & 種子島 浜田漁港 & 漁具 & 山口 & $30-26-24 \mathrm{~N}$ & $130-58-22 \mathrm{E}$ & M.rosa \\
\hline 2010.03 .11 & 種子島 門倉漁港 & 漁具 & 山口 & $30-20-43 \mathrm{~N}$ & $130-52-38 \mathrm{E}$ & \\
\hline
\end{tabular}

Fig. 1. Current geographic distribution of Megabalanus coccopoma (Darwin 1854) in Japan. Pink symbols indicate barnacles attached on the light buoys or floating fishing apperatus. Light blue symbols indicate barnacles growing on rocky shores or the artificial submarine constructions. White symbols indicate absence of M. coccopoma. 1. Kanto and Izu; 2. south Kyushu and Tanegashima Island; 3. Oki Islands and Shimane; 4. Sado Island; 5. Shikoko and west Inland sea; 6. Osaka Bay, west Kii Peninsula and east Inland Sea; 7. north Kyushu and Goto Islands; 8. current geographic distribution of M. coccopoma (Darwin 1854) in four main islands of Japan; 9. living M. coccopoma attached to a buoy for cultivation of "wakame" Seaweed at the Iwai-Takasaki Port, Minami-Boso, Chiba in April 11, 2008. 

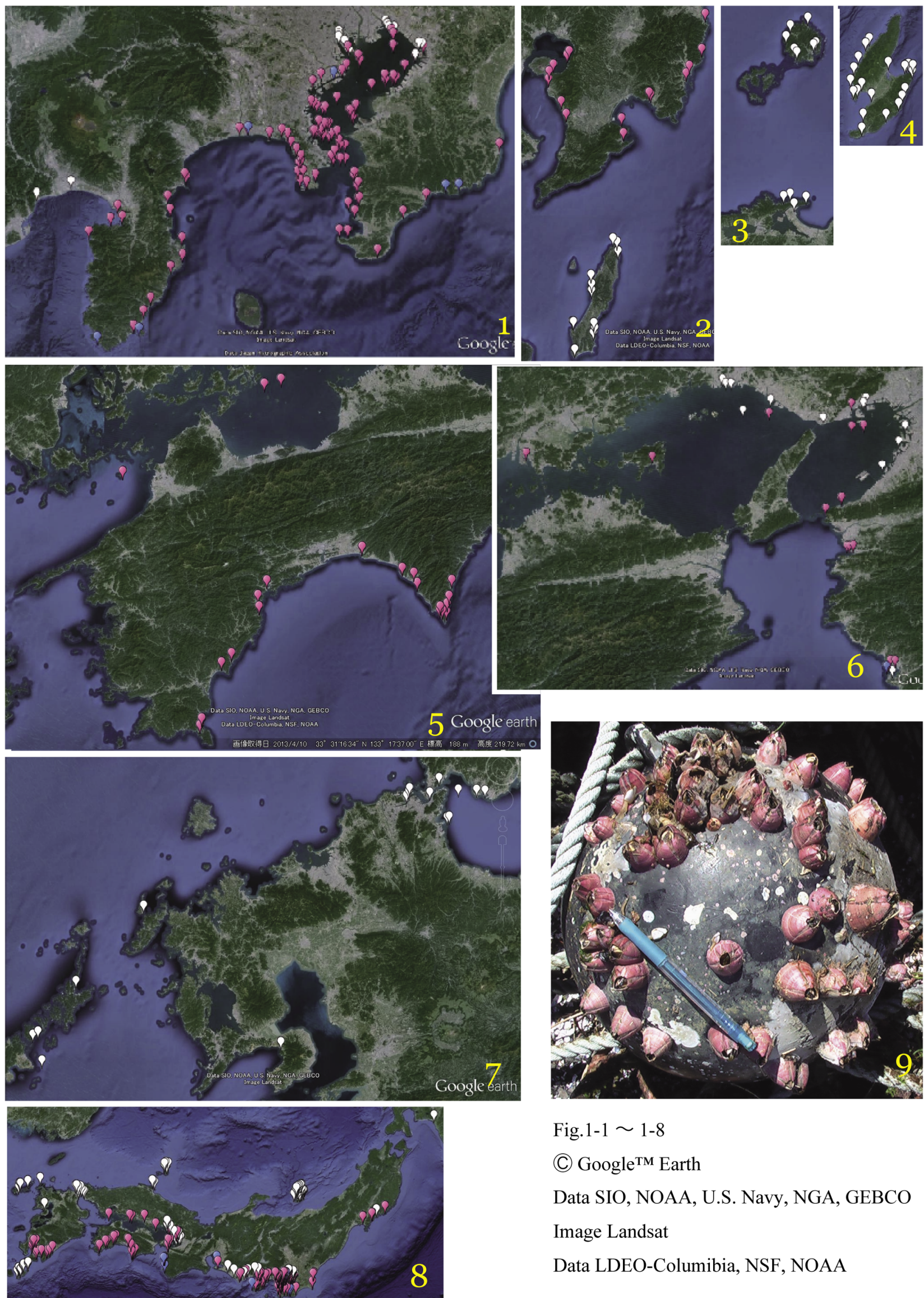

Fig.1-1 1-8

(C) Google ${ }^{\mathrm{TM}}$ Earth

Data SIO, NOAA, U.S. Navy, NGA, GEBCO

Image Landsat

Data LDEO-Columibia, NSF, NOAA 
保管されている。

\section{1. 国内分布の特徵}

ココポーマアカフジッボの現在の北限は、太平洋岸で は岩手県越喜来湾（ホタテ養殖筏）で、南限は鹿児島湾 (定置網) であった。種子島で調査を行ったが、本種を 確認できなかった。

対馬海流の影響する九州西方の対馬周辺から日本海沿 岸の隠岐の島および佐渡島では調査点は少ないが、ココ ポーマアカフジッボの分布を確認できなかった（Fig. 1)。 電力中央研究所・野方靖行（私信）によると、若狭湾の 火力発電所の冷却水にココポーマアカフジッボの幼生の 存在を示す遺伝子レベルの特性を確認できなかったとい う。

東北地方三陸海岸には数か所、東京湾の灯浮標はほぼ 全域、相模湾全域の定置網、伊豆半島、駿河湾、遠州灘、 三河湾、紀伊半島西岸、大阪湾、瀬戸内海の灯浮標、四 国の太平洋岸では高知県室戸岬定置網、九州・日南海岸 から鹿児島湾に分布を確認した。伊勢湾奥の火力発電所 の冷却水にココポーマアカフジッボの幼生の存在を示す 遺伝子レベルの特性が確認できたという（野方私信）。 すなわち東北北部から九州までの太平洋岸の外海から内 湾の岩礁、灯浮標、漁具など 207 地点（2014年7月現在） で分布を確認できた（Table 1, Fig. 1)。

\section{2. 最古のココポーマアカフジツボの採集記録}

1) 海外からの船舶に付着して国内で採集された最古 の記録

2007 年 9 月の発見から 29 年遡る 1978 年 8 月 11 日に中 東から千葉港に入港した出光石油タンカー・徳山丸の船 底から水中で採集された標本 (山口の保存標本) が日本 での最古の採集記録となる（山口ほか, 2011）。しかし これをもって日本への移入・定着とは判断しなかった。 海上交通の発達に伴って船底に付着した状態で日本の港 湾を通過しているフジッボ類は非常に多いと推察され る。日本に越境するだけではなく、繁殖し定着すること が付着生物が外来種となるための必要条件と考える。

ただ1978年当時は国内に同定される種が無く、長期 間標本の存在が顧みられることは無かった。2007年に 国内で発見されるまで 29 年間の空白期間に、本種が本 州北部から九州の太平洋岸に広く分布するようになっ た。

2) 国内の漁具などに付着が確認された最古の記録

1981 年 7 月 27 日に高知県水産試験場・浦吉徳氏が高 知県室戸岬定置網から採集した標本が現時点での最古 の記録になる。この標本も翌年（1982年1月22日）同 じ場所で採集された標本も徳山丸標本と同様に長期に同 定されなかった。室戸標本は定置網から採集されたもの で、日本に侵入した親個体から放出された幼生が、定置 網に付着したと判断され、日本への移入 · 定着が確認さ れた。しかし2007年9月のココポーマアカフジッボの研 究がはじまるまで、標本はココポーマアカフジッボとは 同定されなかった。

\section{考察}

太平洋岸は、三陸海岸では志津川湾、越喜来湾のホ夕 テなどの養殖筏などに付着が確認できたが、岩手県越喜 来湾よりも北の東北地方北部から北海道ではココポーマ アカフジッボは山口自身が行った調查で発見できなかっ た。

日本海沿岸は、太平洋岸に比べて調査地点は少ない が、対馬暖流の流域の長崎県五島列島周辺、島根県隠岐 の島、同美保関、新潟県佐渡島に分布を確認することが できなかった。しかし現在分布していない日本海沿岸へ のココポーマアカフジッボの分散・定着はさほど遠くな いと考える。

九州以南は、種子島だけを精力的に調査を行ったが、 そこにはココポーマアカフジッボは発見されなかった。 種子島よりも南の琉球列島では詳しい調査を行っていな いが、熱帯域にも分布する種であるので、琉球列島南部 に分布する可能性はある。

\section{謝辞}

日本郵船(株)管理の日一豪間鉄鉱石運搬船の船底調査 で本種の付着が確認できたことが本研究の出発点となっ た。海上保安庁の許可を得て第二、三、五、七管区保安 本部の管理下ある航路・灯浮標を、二〜三年間隔で実施 されるメンテナンス時に付着を確認した。また海洋研究 開発機構の「よこすか」、「なつしま」のドック入り時に 船底を調查し、付着を確認した。以上諸機関および日本 海洋事業(株)門馬大和氏に深く感謝の意を表す。また Table 1 に採集者名に表記した大谷道夫、浦吉徳、野方 靖行、堀越彩香、岡本研、周藤拓歩、菊池麻衣、植田育 男、山田和洋、木内将史、深町みどり、坂口勇、羽生田 岳昭、加戸隆介、藤本顕、西川輝明、大和田正人、勝山 一朗、鈴木りさ、真壁美恵、栗原章彦、松本将和、内田 友文（敬称略、順不同）に付着調査の協力を得た。

また本研究は各種の研究経費などで支えられてきた。 千葉大学大学院理学研究科。平成 19 年度 平成 21 年度 環境省地球環境研究総合推進費 II、越境污染（大気・陸 域・海域・国際河川)、地球環境問題対応型研究、D-72 大型船舶のバラスト水・船体付着で越境移動する海洋生 物の動態把握と定着の早期検出（代表者 : 神戸大学・川 井浩史教授）サブテーマ：分子マーカーを利用したフジ ツボ類の起源・移動経路解明に関する研究（研究分担 者：山口寿之)。神奈川大学理学部生物科学科。PICES 2010 (North Pacific Marine Science Organization). 平成 23 年 度〜平成 25 年度マリンバイオ共同推進機構（JAMBIO） 共同利用・共同研究（拠点機関：筑波大学下田臨海実験 センター)。平成 25 年度〜平成 27 年度科学研究費補助 金・基盤研究（B）No.25289326セルオートマトン法に 基づくフジッボ類の船体付着確率と侵入確率予測手法の 研究 (代表者: (独)海上技術安全研究所・亀山道弘).

また本論文のアブストラクトおよび図・表の説明文の英 語査読を、スクリップス海洋研究所の William A. Newman 
氏、琵琶湖博物館の Mark J. Gryger氏から貴重な意見を得 た。さらに二名の査読者からも貴重な意見を得た。

以上ここに記して感謝の意を表す。

\section{引用文献}

Darwin, C. (1854). A Monograph on the Subclass Cirripedia, with figures of all species. The Balanidae, (or Sessile Cirripedes), the Verrucidae, etc., etc., etc. Ray Society, London, 1854, pp.30300.

Yamaguchi, T., R. E. Prabowo., Y. Ohshiro., T. Shimono., D. Jones.,
H. Kawai., M. Otani., A. Oshino., S. Inagawa., T. Akaya and I. Tamura (2009). The introduction to Japan of the Titan barnacle, Megabalanus coccopoma (Darwin, 1854) (Cirripedia: Balanomorpha) and the role of shipping in its translocation. Biofouling, 25, 325-333.

山口寿之・木内将史・堀越彩香 · 岡本 研 · 川井浩史 (2010) 東京湾での外来種ココポーマアカフジッボー2004-2005年 の灯浮標サンプルの再同定. Sessile Organisms, 27, 89-92.

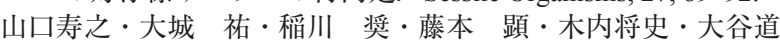
夫・植田育男 · 浦 吉徳 - 野方靖行 ·川井浩史 (2011) 外 来種ココポーマアカフジツボMegabalanus coccopoma (Darwin）の越境と遺伝的特性. 生物の科学遺伝, 65, 90-97. 